\title{
Pengelolaan Anestesi untuk Bedah Laparoskopik dengan Emfisema Subkutis Intraoperatif
}

\author{
RTH Soepraptomo \\ Departemen Anestesiologi dan Terapi Intensif RSUD Dr. Moewardi Surakarta Fakultas Kedokteran Universitas \\ Sebelas Maret
}

\begin{abstract}
Abstrak
Laparoskopi telah berkembang dari prosedur bedah ginekologis terbatas yang hanya digunakan untuk diagnosis dan ligasi tuba menjadi alat bedah utama yang digunakan untuk banyak indikasi ginekologis. Emfisema subkutis adalah komplikasi dari bedah laparoskopik. Studi ini membahas pengelolaan anestesi untuk bedah laparoskopik dengan emfisema subkutis. Seorang wanita 37 tahun dengan adenomiosis dan kista coklat sinistra dengan rencana operasi reseksi adenomiosis dan kistektomi perlaparoskopi dengan status fisik ASA II Plan general anesthesia endotracheal tube (GAET). Operasi dilakukan tanggal 15 Oktober 2018, dengan durante operasi 5 jam. Saat infraoperatif, emfisema subkutis ditemukan dari diafragma hingga thorax. Emfisema subkutis dicurigai disebabkan karena terjadi penurunan kondisi pasien menjadi head down extreme (Trendelenburg position), dan insuflasi $\mathrm{CO}_{2}$ yang cukup ekstrim hingga 15-20 mmHg. Faktor tambahan lain juga disebabkan oleh banyaknya jaringan adiposa (IMT $32 \mathrm{~kg} / \mathrm{m}^{2}$ ) sehingga menyulitkan operator untuk visualisasi pada lapang operasi. Pemantauan yang ketat selama durante operasi dan kepiawaian ahli anestesi dalam mendiagnosis serta melakukan intervensi respirasi merupakan hal yang krusial dalam mengendalikan kondisi emfisema subkutis agar tidak bertambah komplikasinya.
\end{abstract}

Kata kunci: Emfisema subkutis, laparoskopi, anestesi umum

\section{Anesthetic Management of Laparoscopic Surgery in Intraoperative Subcutaneous Emphysema}

\begin{abstract}
Laparoscopy has evolved from a limited gynecological surgical procedure used only for diagnosis and tubal ligation to become the main surgical tool used for many gynecologic indications. Subcutaneous emphysema is a complication of laparoscopic surgery. This study discusses anesthetic management for laparoscopic surgery with subcutaneous emphysema. A 37-year-old woman with Adenomyosis and left chocolate cyst with planned surgical resection of adenomyosis and laparoscopic cystectomy with ASA II physical status Plan GAET. The operation was carried out on October 15 2018, with an operation duration of 5 hours. Intraoperatively, subcutaneous emphysema was found from the diaphragm to the thorax. Subcutaneous emphysema is suspected to be caused by such conditions that the patient's decline to head down extreme (Trendelenburg position), and $\mathrm{CO}_{2}$ insufflation which is quite extreme up to $15-20 \mathrm{mmHg}$. Another additional factor is the large amount of adipose tissue (BMI 32) which makes it difficult for the operator to visualize the operating field. Close monitoring during surgery and the expertise of the anesthesiologist in diagnosing and performing respiratory interventions are crucial in controlling the condition of subcutaneous emphysema so as not to increase its complications.
\end{abstract}

Key words: subcutaneous emphysema, laparoscopy, general anesthesia 


\section{Pendahuluan}

Penggunaan laparoskopi telah merevolusi bidang bedah dengan keuntungannya mengurangi morbiditas dengan pemulihan dini. Prosedur laparoskopi telah dilakukan secara tradisional di bawah anestesi umum (general anesthesia/GA) karena perubahan pernapasan yang disebabkan oleh pneumoperitoneum, yang merupakan bagian integral dari laparoskopi. Selama 50 tahun terakhir, laparoskopi telah berkembang dari prosedur bedah ginekologis terbatas yang hanya digunakan untuk diagnosis dan ligasi tuba menjadi alat bedah utama yang digunakan untuk banyak indikasi ginekologis dan non ginekologis. Saat ini, laparoskopi adalah salah satu prosedur bedah paling umum yang dilakukan di banyak bagian dunia. Untuk hampir seluruh prosedur ginekologi, seperti pengangkatan kehamilan ektopik, perawatan endometriosis, kistektomi ovarium dan histerektomi, laparoskopi telah menjadi pilihan perawatan. Dibandingkan dengan laparotomi, banyak penelitian menunjukkan laparoskopi lebih aman, lebih murah, dan memiliki waktu pemulihan yang lebih singkat. Keuntungan dari pendekatan laparoskopi untuk prosedur lain, termasuk miomektomi, colpopexy sakral, dan pementasan serta pengobatan kanker ginekologi, terus meluas sub. ${ }^{1}$

Kontrol ventilasi yang presisi dalam kondisi secara terkendali pada GA telah membuktikan sangat ideal untuk prosedur tersebut. Namun, baru-baru ini penggunaan anestesi regional (anestesi regional/RA) telah muncul sebagai pilihan alternatif untuk laparoskopi. Berbagai laporan dalam literatur menunjukkan keamanan penggunaan anestesi kombinasi spinal-epidural, spinal, dan epidural dalam prosedur laparoskopi. Keuntungan RA dapat mencakup pencegahan manipulasi jalan napas, pasien yang sadar dan napas spontan intraoperatif, mual dan muntah minimal, analgesia pasca operasi yang efektif, dan ambulasi dan pemulihan dini. Namun, RA dapat dikaitkan dengan beberapa efek samping seperti kebutuhan tingkat sensorik yang lebih tinggi, hipotensi yang lebih parah, ketidaknyamanan bahu karena iritasi diafragma, dan rasa malu pernafasan yang disebabkan oleh pneumoperitoneum.
Penelitian lebih lanjut mungkin diperlukan untuk menetapkan keunggulan RA dibandingkan GA untuk penggunaan globalnya pada populasi pasien yang berbeda. ${ }^{2}$

Pengenalan laparoskopi di bidang pembedahan pada pertengahan 1950-an merevolusi teknik bedah karena pengurangan biaya medis secara keseluruhan, mengurangi perdarahan, lebih sedikit komplikasi bedah dan paru pasca operasi, dan pemulihan dini. Pergeseran laparoskopi secara bertahap untuk memasukkan prosedur bedah yang lebih rumit menghasilkan modifikasi teknik anestesi yang ada. Berbagai efek induksi pneumoperitoneum, bagian integral dari laparoskopi, dapat menyebabkan perubahan pernapasan dan kardiovaskular sehingga paling baik dikelola dengan menggunakan anestesi GA. Sejak dimulainya penerapan laparoskopi di berbagai operasi anak, teknik anestesi yang lebih baik diperlukan yang memungkinkan pemulihan dini dan ambulasi. Evolusi obat anestesi pada skala yang relevan secara ilmiah dan klinis telah mendorong inovasi dan inisiatif untuk teknik yang lebih baru namun lebih aman. Kemajuan dalam anestesiologi telah dibuat di banyak bidang selain skala yang relevan secara klinis. ${ }^{3}$

Sebaliknya, kemajuan dalam teknik anestesi dan obat-obatan di era modern telah melahirkan dan berkembang menjadi kontroversi baru dalam terang bukti ilmiah baru. Secara tradisional, GA dianggap sebagaisatu-satunya teknik, dan berbagai mitos dan fakta tidak mendukung penggunaan RA. Di antara ini, gangguan pernapasan dan perubahan kardiovaskular adalah aspek utama dari kekhawatiran yang dianggap paling baik dikelola dengan penggunaan GA. Selain itu, ahli anestesi lebih nyaman dengan pemberian GA dalam operasi laparoskopi, dan ada keengganan umum untuk mengambil inisiatif untuk kemajuan dalam pertukaran teknik anestesi. Baru-baru ini, RA telah didokumentasikan memiliki hasil yang sama baiknya dalam operasi laparoskopi. ${ }^{4}$ Prosedur laparoskopi secara keseluruhan dianggap aman, dengan tingkat komplikasi serius yang rendah, yang hingga $50 \%$ terjadi saat mendapatkan akses perut atau pada saat penempatan port. Sedangkan komplikasi lainnya terjadi selama insuflasi abdomen, diseksi 
jaringan dan hemostasis. Gas insuflasi utama yang digunakan dalam prosedur laparoskopi untuk membuat pneumoperitoneum adalah $\mathrm{CO}_{2}$, yang lebih disukai daripada gas lain karena kelarutannya yang tinggi. Beberapa komplikasi yang kurang umum terjadi selama $\mathrm{CO}_{2}$ insuflasi termasuk pneumotoraks, Emfisema Subkutis, pneumomediastinum dan ekstravasasi retroperitoneal tanpa pneumotoraks. Emfisema subkutis juga ditemukan sebagai komplikasi dari prosedur laparoskopi ekstraperitoneal dan intraperitoneal.

Faktor risiko yang berhubungan dengan emfisema subkutis termasuk penggunaan $>5$ kanula dan prosedur yang berlangsung $>3,5$ jam. Selanjutnya, gerakan berulang berkontribusi pada pengembangan komplikasi karena gangguan integritas jaringan dan kelemahan struktural yang diakibatkannya. Kenaikan tingkat $\mathrm{ETCO}_{2}$ diluar kisaran normal telah sering dikaitkan dengan asidosis pernapasan, terutama di hadapan riwayat penyakit kardiovaskular. $^{2}$ Karena sebagian besar kasus komplikasi tersebut tidak terdeteksi, ahli anestesi harus waspada dan menyadari faktor risikonya. Identifikasi tanda-tanda, seperti hiperkarbia mendadak atau persisten atau adanya krepitasi, secara klinis pada tahap awal perkembangan emfisema subkutis dapat membantu mencegah dan mengelola kasus tersebut secara lebih efektif. Emfisema subkutis cenderung sembuh secara spontan dalam banyak kasus; karena tingkat difusi $\mathrm{CO}_{2}$ yang tinggi, dibutuhkan waktu hingga 24 jam untuk menatalaksana emfisema subkutis. Namun, pasien harus dipantau secara ketat. Pengobatan andalan untuk emfisema subkutis adalah desuflasi peritoneal. Selanjutnya, radiografi dada intraoperatif dan analisis gas darah arteri dapat digunakan untuk menyingkirkan perbedaan lainnya. Dalam kasus emfisema subkutis yang parah, intervensi bedah, seperti drainase dan insisi, terkadang diperlukan untuk mengurangi tekanan. ${ }^{5}$ Pada studi ini akan dibahas mengenai manajemen anestesi bedah laparoskopi dengan emfisema subkutis intaoperatif.

\section{Kasus}

Riwayat penyakit
Pada tanggal 13 Oktober 2018, datang seorang wanita usia 37 tahun dengan keluhan utama nyeri perut sebelah kiri. Pasien mengaku sakit perut sebelah kiri sudah dirasakan sejak setahun ini. Mual muntah (-). Batuk pilek (-) mens lancar sebulan sekali. Pasien memiliki riwayat hipertensi dan diabetes melitus sejak 2017. DM terkontrol insulin 10 IU pagi, 8 IU malam.

\section{Pemeriksaan Fisik}

Kondisi pasien sadar penuh, GCS E4V5M6. Pasien memiliki tekanan darah 130/80 $\mathrm{mmHg}$, nadi $88 \mathrm{x} /$ menit, laju respirasi $16 \mathrm{x} / \mathrm{menit}$, suhu $36,4{ }^{\circ} \mathrm{C}$, dan saturasi oksigen $100 \%$ dengan $\mathrm{O}_{2}$ nasal kanul $3 \mathrm{lpm}$. Pasien memiliki berat badan $75 \mathrm{~kg}$, tinggi badan $154 \mathrm{~cm}$, indeks massa tubuh 31,65 . Airway bebas, patensi hidung $(+/+)$, deviasi septum (-/-), buka mulut $>3$ jari, mallampati 3, gigi dalam batas normal, gerak leher bebas, TMD $5 \mathrm{~cm}$. Breathing: thoraks bentuk normochest, simetris, pengembangan dada kanan=kiri, retraksi (-/-), otot bantu nafas (-/-), sonor/sonor, suara dasar vesikuler $(+/+)$, suara tambahan $(-/-$ ), frekuensi nafas 20x/menit. Circulation: bunyi jantung I-II reguler, bising (-). Tekanan darah $130 / 80 \mathrm{mmHg}$, nadi $88 \mathrm{x} / \mathrm{menit}$, irama teratur, isi cukup, CRT $<2$ detik, akral dingin (-/-). Disability: GCS E4V5M6, pupil isokor dengan diameter $3 \mathrm{~mm} / 3 \mathrm{~mm}$, reflek cahaya $(+/+)$.

\section{Pemeriksaan Penunjang}

Pada pemeriksaan thorax ditemukan perkusi sonor di seluruh lapang paru, auskultasi terdengar suara dasar: vesikuler $(+/+)$, suara tambahan: ronki basah halus (RBH) (-/-), ronki basah kasar (RBK) (-/-), wheezing (-/-). Pada pemeriksaan jantung $\mathrm{BJ}_{1-2}$ tunggal, irama reguler, murmur (-). Pada pemeriksaan abdomen teraba abdomen supel, nyeri tekan (-), perkusi abdomen timpani, auskultasi abdomen bising usus dalam batas normal. Akral hangat, tidak didapatkan oedema di seluruh ekstremitas. Hasil Elektrokardiogram (EKG) menunjukkan sinus rhytm, heart rate $92 \mathrm{bpm}$, normoaksis. Dari hasil foto thorax didapatkan kesan pulmo tak tampak kelainan, cor tak valid dinilai. Dari hasil USG, didapatkan kandung kemih terisi cukup, uterus bentuk dan ukuran dbn, tampak massa hipoechoic ukuran $4.55 \times 4.52 \times 3.05 \mathrm{~cm}$. 
Tabel 1. Pemeriksaan Laboratorium 13 Oktober 2018

\begin{tabular}{llll}
\hline Pemeriksaan & Hasil & Satuan & Rujukan \\
\hline DARAH RUTIN & & & \\
Hemoglobin & 13.6 & $\mathrm{~g} / \mathrm{dL}$ & $12.0-15.6$ \\
Hematokrit & 39 & $\%$ & $33-45$ \\
Leukosit & 9.1 & $\mathrm{ribu} / \mathrm{ul}$ & $4.5-11.0$ \\
Trombosit & 398 & $\mathrm{ribu} / \mathrm{ul}$ & $150-450$ \\
Eritrosit & 4.56 & juta/ul & $4.10-5.10$ \\
HEMOSTASIS & & & \\
PT & 13.7 & Detik & $10.0-15.0$ \\
APTT & 32.5 & Detik & $20.0-40.0$ \\
INR & 1.090 & & \\
KIMIA KLINIK & & & \\
Glukosa darah sewaktu & 101 & $\mathrm{mg} / \mathrm{dl}$ & $60-140$ \\
ELEKTROLIT & & & \\
Natrium darah & 136 & $\mathrm{mmol} / \mathrm{L}$ & $136-145$ \\
Kalium darah & 4.2 & $\mathrm{mmol} / \mathrm{L}$ & $3.3-5.1$ \\
Chloride darah & 100 & mmol/L & $98-106$ \\
SEROLOGI HEPATITIS & & & Nonreactive \\
HbsAg Rapid & Nonreactive & & \\
\hline
\end{tabular}

Kesan menyokong gambaran kista coklat dengan status fisik ASA II Plan general anesthesia endotracheal tube (GAET). Selanjutnya pasien

Pengelolaan Anestesi

Berdasarkan kondisi pasien, diagnosis anestesi sebagai berikut: wanita 37 tahun dengan adenomiosis + kista coklat sinistra pro reseksi adenomiosis + kistektomi perlaparoskopi dilakukan persiapan operasi antara lain, keluarga diberi penjelasan tentang rencana yang akan dilakukan, prosedur tindakan anestesi dan operasi, kemungkinan hal-hal yang bisa terjadi selama tindakan dan alternatif tindakan menghadapi

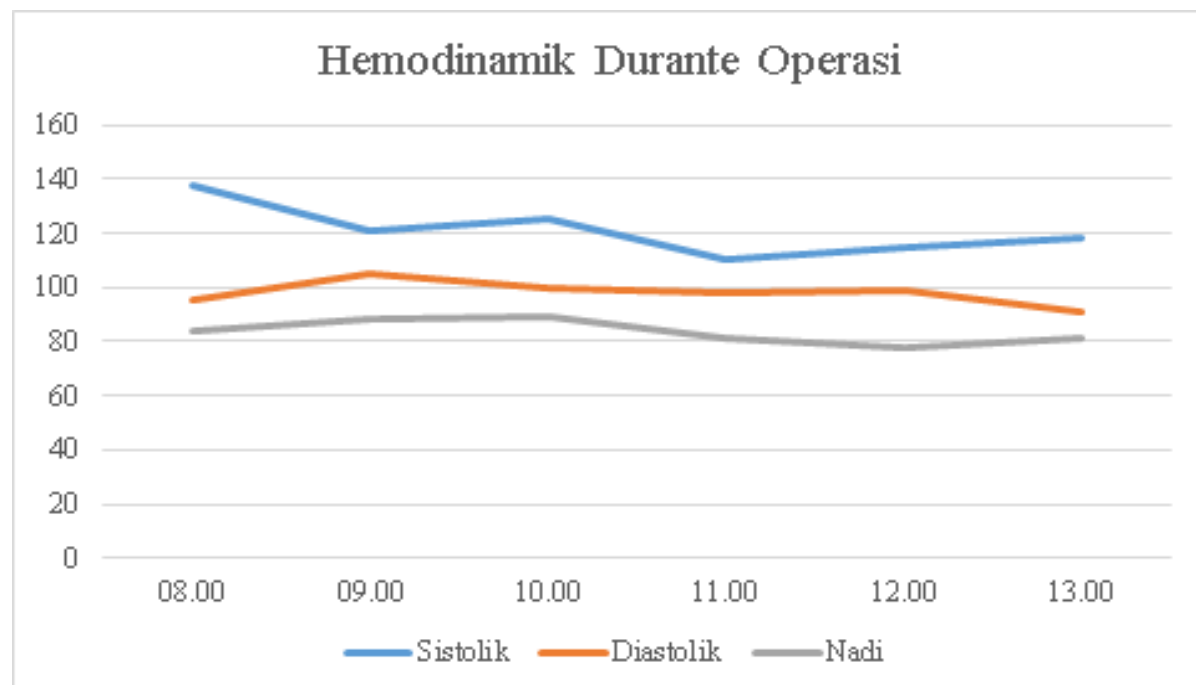

Gambar 1. Hemodinamik Durante Operasi 
resiko operasi, persiapan obat dan alat. Setelah persiapan pre-operasi siap, dimulai pelaksanaan operasi. Pasien masuk ruang operasi pada tanggal 15 Oktober 2018 pukul 08.00, dilakukan pemasanganlead EKG, saturasioksigen, tekanan darah, dan pengukuran suhu tubuh.

Didapatkan data tanda vital tekanan darah 138/95, denyut jantung 84x/menit, frekuensi nafas $18 \mathrm{x} /$ menit, temperatur $36,3^{\circ}$, saturasi $\mathrm{O}_{2} 100 \%$, EKG irama sinus. Diberikan preoksigenisasi pada pasien dengan $\mathrm{O}_{2}$ murni $8 \mathrm{lpm}$ dengan posisi supine. Kemudian diberikan koinduksi dengan midazolam $2 \mathrm{mg}, 5$ menit setelahnya dilanjutkan dengan pemberian fentanyl $150 \mathrm{mcg}(\sim 2 \mathrm{mcg} / \mathrm{kg})$ perlahan, dilanjutkan 3 menit setelahnya dengan Propofol $70 \mathrm{mg}(\sim 1 \mathrm{mg} / \mathrm{kg})$. Setelah airway terkuasai dengan sempurna, maka pelumpuh otot diberikan. Pelumpuh otot digunakan atracrium $35 \mathrm{mg}(0,5$ $\mathrm{mg} / \mathrm{kg}$ ). Ditunggu hingga onset tercapai dengan waktu 3,5 menit bersamaan dengan pembukaan gas sevoflurane $1 \mathrm{vol} \%$. Kemudian dilakukan intubasi dengan menggunakan direk laringoskopi dengan blade MAC 3.0, dan dilakukan pemasangan ETT 7,0. Memastikan kedalaman ETT dengan level $19 \mathrm{~cm}$ dan dilakukan fiksasi serta pemasangan monitoring $\mathrm{ETCO}_{2}$. Dilakukan pemasangan $i v$ line di vena radialis kiri (2 jalur). Rumatan anestesi dengan sevoflurane 1.5-2 vol $\%$ dan $\mathrm{O}_{2}: \mathrm{N}_{2} \mathrm{O}=2: 2$. Dengan pemberian analgesik intraoperatif fentanyl $0.5-1 \mathrm{mcg} /$ $\mathrm{kgbb} / \mathrm{jam}$, dan atracrium $5-10 \mathrm{mcg} / \mathrm{kg} / \mathrm{min}$. Operasi dimulai pukul 08.00 berjalan selama 5 jam. Operasi selesai hingga pukul 13.00. Durante operasi kisaran TD adalah sistolik 100- 120 mmHg. TD diastolik berkisar di $60-80 \mathrm{mmHg}$, MAP 64-113 mmHg, nadi pasien 58-88 x/ menit, dan saturasi $\mathrm{O}_{2} 99-100 \%$. ETCO 2 durante operasi pada jam awal operasi (08.00-10.00) berkisar di antara 30-35 mmHg, menggunakan respirasi kontrol volume control ventilation (VCV) TV 350mL, RR 14x/m, I:E = 1:2, PEEP = 6 , bersamaan dengan ini posisi pasien dilakukan head down sebanyak 5' dan Pressure Insuflasi Intraabdomen dengan menggunakan $\mathrm{CO}_{2}$ hingga $12 \mathrm{mmHg}$. Pukul (10.30) operator meminta untuk meningkatkan tekanan insuflasi $\mathrm{CO}_{2}$ hingga 15-20 mmHg dan head down cukup ekstrim 30'.
Pada 1 menit pertama, nilai ET $\mathrm{CO}_{2}$ belum meningkat. Pada menit kedua, ET $\mathrm{CO}_{2}$ meningkat secara drastis hingga $45 \mathrm{mmHg}$, TD 130/90, N 88x/m, $\mathrm{SpO}_{2}$ 96\%. Mode Respirasi Kontrol diubah dengan menaikkan RR sebanyak 20x/m dan I:E=1:3 $\mathrm{O}_{2}:$ Air bar $=$ 3:1. $\mathrm{ETCO}_{2}$ berangsur menurun dan $\mathrm{ETCO}_{2}$ bertahan di angka $42 \mathrm{mmHG}$ (pukul 10.05). Ditemukan juga terdapat emfisema subkutis saat pukul 10.05 dari diafragma hingga thorax.

Dengan kondisi seperti ini, maka Insuflasi kembali diturunkan menjadi 10-12 mmHg dan head down di kembalikan ke posisi yang lebih memudahkan bagi kondisi pasien untuk mengurangi terjadinya penurunan komplians paru $\left(5-15^{\prime}\right)$. Emfisema Subkutis di bagian thorax meluas hingga pukul 11.00 dengan kondisi ETCO $_{2}$ sudah menurun hingga $35 \mathrm{mmHG}$ dari pukul 10.20, meluas ke arah bagian neck circumference. Pada pukul 12.00, $\mathrm{ETCO}_{2}$ mengalami penurunan yang cukup baik, berkisar antara (30-35 mmHG) dan emfisema subkutis yang berada di neck circumference berangsur berkurang, dan hanya tinggal di bagian regio thorakal. Pada pukul 12.00-12.30, operasi berjalan dengan baik dan dilakukan penjahitan. Posisi dinetralkan, insuflasi abdomen dimatikan, dan $\mathrm{ETCO}_{2}$ kembali ke rentang normal 30-35 mmHG, disertai pengurangan krepitasi emfisema yang cukup baik.

\section{Pengelolaan Pascabedah}

Kondisi pascabedah pasien dalam kondisi keadaan umum baik, hemodinamik stabil, nafas spontan dan saturasi $99 \%$ dengan suplementasi oksigen via nasal kanul $3 \mathrm{lpm}$. Pasien diobservasi di recovery room selama 2 jam. Pukul 15.30. Kondisi pasien baik, dengan TD 148/89, N 104x/m, RR18x/m, $\mathrm{SpO}_{2}$ 99\% produk $\mathrm{O}_{2} 31 \mathrm{pm}$ nasal kanul (NK), tidak ada mual dan muntah, post operasi diberikan analgetik paracetamol 1gram/8jam intravena, kemudian pasien dipindahkan ke ruang perawatan.

\section{Pembahasan}

Laparoskopi adalah suatu proses inspeksi bagian dalam rongga perut dengan menggunakan endoskop melalui akses yang minimal. Untuk 
mendapatkan lapang pandang yang baik dalam rongga perut diperlukan pneumoperitoneum, yaitu insulflasi ronga peritoneum dengan gas $\mathrm{CO}_{2}$. Prosedur ini ditambah dengan posisi pasien yang seringkali ekstrim, membawa dampak fisiologik yang bermakna. Pengetahuan dan pemahaman mengenai hal ini sangat penting untuk manajemen anestesia yang baik. ${ }^{6}$ Penggunaan teknik laparoskopi telah sangat maju dan dapat diteapkan untuk banyak prosedur. Saat ini laparoskopi telah menjadi prosedur operasi tersering bagi pasien rawat jalan. ${ }^{7}$ Pembedahan laparoskopik disukai karena minimally invasive dan dihubungkan dengan penyembuhan luka yang lebih cepat, Meski demikian pada pasien dengan kondisi buruk tindakan laparoskopi mungkinsulit untuk dilakukan karena perubahan-perubahan fisiologik diatas. Anestesia harus dilakukan secara berhati-hati dan disesuaikan dengan jenis operasi dan kondisi pasien. ${ }^{5}$

Pada pasien ini, pada saat dilakukan pembedahan laparoskopi, terjadi kondisi yang tidak diinginkan yaitu emfisema subkutis. Hal ini dicurigai disebabkan karena kondisi yang sedemikian rupa sehingga Penurunan pasien menjadi head down extreme (Trendelenburg position), dan insuflasi $\mathrm{CO}_{2}$ yang cukup extreme hingga $15-20 \mathrm{mmHg}$. Faktor tambahan lain juga disebabkan oleh banyaknya jaringan adiposa (BMI 32) sehingga menyulitkan operator untuk visualisasi pada lapang operasi. ${ }^{8}$ Pemantauan yang ketat selama durante operasi, dankepiawaian ahlianestesidalam mendiagnosis dan melakukan intervensi respirasi merupakan hal yang krusial dalam mengendalikan kondisi ini agar tidak bertambah komplikasinya. Selama pneumoperitoneum kontrol ventilasi disesuaikan untuk mempertahankan $\mathrm{PETCO}_{2}$ kirakira 30-35 mmHg, untuk ini membutuhkan tak lebih dari $15-25 \%$ peningkatan ventilasi semenit, kecualibila terjadi emfisema subcutis. Peningkatan frekuensi nafas lebih dipilih daripada peningkatan volume tidal pada pasien dengan penyakit paru obstruktif kronik (PPOK) dan pada pasien dengan pneumothorak spontan atau emfisema subkutis untuk menghindari peningkatan inflasi alveolar dan menurunkan resiko pneumothorak. ${ }^{9}$ Tekanan intraabdomen harus dimonitor, dipertahankan serendah mungkin untuk mengurangi perubahan hemodinamik dan respirasi, dan tidak boleh lebih dari $20 \mathrm{mmHg}$, secara relatif sebaiknya dijaga di bawah 12 mmHg. Peningkatan tekanan intraabdomen dapat dihindari dengan menjaga kedalaman anestesi. Karena kecenderungan terjadi refleks peningkatan tonus vagus selama laparoskopi, atropine harus disediakan untuk injeksi jika diperlukan. ${ }^{10}$

\section{Simpulan}

Prosedur laparoskopi secara keseluruhan dianggap aman, dengan tingkat komplikasi serius yang rendah. Emfisema subkutis juga ditemukan sebagai komplikasi dari prosedur laparoskopi ekstraperitoneal dan intraperitoneal. Identifikasi tanda-tanda, seperti hiperkarbia mendadak atau persisten atau adanya krepitasi, secara klinis pada tahap awal perkembangan emfisema subkutis dapat membantu mencegah dan mengelola kasus tersebut secara lebih efektif. Pengobatan andalan untuk emfisema subkutis adalah desuflasi peritoneal. Selanjutnya, radiografi dada intraoperatif dan analisis gas darah arteri dapat digunakan untuk menyingkirkan perbedaan lainnya. Dalam kasus emfisema subkutis yang parah, intervensi bedah, seperti drainase dan insisi, terkadang diperlukan untuk mengurangi tekanan.

\section{Daftar Pustaka}

1. Asano R, Suzuki Y, Saito S, Kamiya N, Aoki M, Miyagi E. Massive subcutaneous emphysema extending to the face during total laparoscopic hysterectomy. J Minim Invasive Gynecol. 2019;26(4):589-90

2. Jones A, Pisano U, Elsobky S, Watson AJM. Grossly delayed massive subcutaneous emphysema following laparoscopic left hemicolectomy: A case report. Int J Surg Case Rep. 2015;6:277-79.

3. Ko ML. Pneumopericardium and Severe Subcutaneous Emphysema after Laparoscopic Surgery. J Minim Invasive Gynecol. 2010;17(4):531-33. 
4. Uhm S, Gujral H, Wright $\mathrm{K}$, Wright V. Subcutaneous emphysema in laparoscopic surgery. J Minim Invasive Gynecol. 2016;23(7):S136.

5. Pandita S, Kattamanchi A, Chaudhary O, Kaul P. Severe subcutaneous emphysema after robotic laparoscopic hiatal hernia repair. Chest. 2018;154(4):52A.

6. McLennan RJ, Lefebvre CW. Subcutaneous emphysema in the lower extremities-always an emergency? complications from minimally invasive surgery-a case report. J Emerg Med. 2015;48(2):e31-e33.

7. Zhang JL, Wang J, Li RQ, Tang JC. Subcutaneous emphysema and buccopharyngeal submucosal emphysema after retroperitoneal laparoscopic surgery and upper airway obstruction. Br J Anaesth.
2013;110(2):317-18.

8. Jaafar S, Hung Fong S Sen, Waheed A, Misra S, Chavda K. Pneumoretroperitoneum with subcutaneous emphysema after a post colonoscopy colonic perforation. Int J Surg Case Rep. 2019;58:117-20.

9. Ng VS, Harris TJ, Guan X. Hypercarbia and subcutaneous emphysema in a patient undergoing laparoscopic myomectomy. J Minim Invasive Gynecol. 2012;19(6):S144-S145.

10. Lee DW, Kim MJ, Lee YK, Lee HN. Does intraabdominal pressure affect development of subcutaneous emphysema at gynecologic laparoscopy? J Minim Invasive Gynecol. 2011;18(6):761-65. 